\title{
Penerapan Sistem Pakar Menggunakan Metode Fuzzy Sugeno Identifikasi Hama Tanaman Padi
}

\author{
Odi Nurdiawan*1, Ayu Nur Pusvitasari ${ }^{2}$ \\ 1,2 Jln Perjuangan No 10 B Majasem Kesambi Kota Cirebon \\ ${ }^{1,2}$ Jurusan Teknologi Informasi, STMIK IKMI Cirebon \\ e-mail: 1 odynurdiawan@gmail.com, ${ }^{2}$ ayunurpusvitasari@gmail.com
}

\begin{abstract}
Abstrak
Para petani tanaman padi mengalami berbagai permasalahan dalam menangani hama pada tanamn padi. Menurut Kepala BPP (Badan Pelaksana Penyuluhan) Kabupaten Tegal, hama pada tanaman padi memberikan banyak kerugian salah satunya gagal panen. Berdasarkan data komoditas produksi tanaman padi dari tahun 2010 - 2015 mengalami kondisi naik turun, dimana pada tahun 2010 produksi padi mengalami kenaikan yang cukup tinggi sebanyak 368.450,57 ton turun drastis di tahun 2013 sebanyak 211.543,33 ton hingga di tahun 2015 hanya mengalami sedikit kenaikan sebanyak 317,821,16 ton. Beberapa masalah yang menyerang tanaman padi yang menyebabkan gagal panen adalah kurangnya pengetahuan petani dalam menangani masalah hama padi diantaranya hama tikus, hama penggerek batang, hama wereng coklat, hama wereng hijau, hama keong mas, hama putih palsu, hama ganjur. Penelitian ini menggunakan metode sugeno, dimana tahapan metode fuzzy sugeno adalah Pembentukan himpunanFuzzymengaplikasikan fungsi implikasi (aturan). Komposisi aturan, didapat dari kumpulan data hubungan antar aturan. Penegasan (Defuzzifikasi), input dari defuzzifikasi adalah konstanta atau persamaan linier. Penelitian ini dapat menghasilkan perangkat lunak yang dapat membantu para petani memecahkan permasalahan dalam mendiagnosis hama tanaman padi, yang didasarkan pada gejala-gejala yang ditemukan di lapangan. serta dapat memberikan solusi yang baik berupa hasil jenis hama yang ditimbulkan, cara pengendaliannya, pengobatan, penanggulangan nya.
\end{abstract}

Kata kunci-Sistem Pakar, Sugeno, Fuzzy, Hama, Padi

\section{Abstract}

Paddy farmers have various problems in handling rice pests. According to the Head of BPP Kabupaten Tegal, rice plant pests give a lot of losses, one of which failed to harvest. Based on data from rice production from 2010 to 2015 have ups and downs, where in 2010 rice production increased quite high as many as 368,450.57 tons fell drastically in 2013 as much as $211,543.33$ tons until in 2015 only slightly increased as much as 317.821, 16 tons. Some of the problems affecting rice crops that cause crop failure are the lack of knowledge of farmers in handling rice pest problems such as rat pests, stem borers, brown plant hopper pests, green leafhopper pests, snail pests, fake white pests, gamur. This study uses sugeno method, where fuzzy sugeno phase is a Fuzzy arrangement that implements the function of implication (rule). The composition of rules, derived from the data set of relationships between rules. Affirmation (Defuzzification), the input of defuzzification is a constant or a linear equation. This research can produce software that can help farmers solve problems in diagnosing rice pests, based on the symptoms found in the field. and can provide a good solution in the form of the results of the type of pest inflicted, the way of control, treatment, handling.

Keywords-Expert System, Sugeno, Fuzzy, Pest, Rice 


\section{PENDAHULUAN}

Secara administratif wilayah kabupaten Tegal terbagi menjadi 18 Kecamatan, dengan luas wilayah $878.79 \mathrm{~km}^{2}$, seluruhnya berada pada ketinggian antara \pm 0 -1600 mdpl (Meter di atas permukaan laut). Kabupaten Tegal merupakan salah satu daerah yang memperoleh penghargaan dari Presiden RI atas keberhasilannya dalam meningkatkan produksi padi yang mencapai 368.458,57 ton gabah, sekitar 60 persen penduduk didaerah Kabupaten Tegal bekerja pada sektor pertanian, yang mayoritas penduduknya bermata pencaharian sebagai petani padi. Dalam usaha penanaman padi salah satu resiko yang dihadapi oleh petani adalah adanya hama tanaman padi yang terlambat untuk di diagnosis dan sudah mencapai tahap yang parah, sehingga menyebabkan terjadinya gagal panen. Oleh karena itu, mengenal gejala dari masing masing hama pada tanaman padi merupakan hal yang sangat penting bagi suksesnya proses penanaman padi.

Menurut Yulianto dkk dalam penelitiannya yang berjudul Model Sistem Pakar Diagnosa Hama Tanaman Padi untuk memberikan solusi penanggulangan, menyatakan bahwa: "Padi merupakan sumber karbohidrat utama bagi mayoritas penduduk dunia salah satunya penduduk Indonesia. Padi mempunyai daun tunggal berbentuk pita yang panjangnya $15-30 \mathrm{~cm}$. Ujungnya runcing, tepinya rata, berpelepah, pertulangan sejajar, dan berwarna hijau. Buahnya keras dan terjurai pada tangkai. Setelah tua, warna hijau akan menjadi kuning. Bijinya keras, berbentuk bulat telur, ada yang berwarna putih atau merah. Tanaman ini merupakan tanaman yang berbatang basah, dengan tinggi antara $50 \mathrm{~cm}-1,5 \mathrm{~m}$. Batangnya tegak, lunak, beruas, berongga, kasar dan berwarna hijau. Pada umumnya beras berwarna putih, walaupun ada juga beras yang berwarna merah. Padi yang termasuk keluarga rumput -rumputan ini ditanam dari bijinya secara langsung atau melalui persemaian dahulu. [7]

Menurut Muhamad Arsyad dalam penelitiannya yang berjudul Implementasi Metode Sugeno Pada Sistem Pakar Penentuan Stadium Pada Penyakit Tubercolosis (TBC). menyatakan bahwa: "Penalaran dengan metode Sugeno hampir sama dengan penalaran Mamdani, hanya saja output (konsekuen) sistem tidak berupa himpunan fuzzy, melainkan berupa konstanta atau persamaan linear. Sistem fuzzy Sugeno memperbaiki kelemahan yang dimiliki oleh sistem fuzzy murni untuk menambah suatu perhitungan matematika sederhana sebagai bagian THEN. Pada perubahan ini, sistem fuzzy memiliki suatu nilai rata-rata tertimbang (Weighted Average Values) di dalam bagian aturan fuzzyIF-THEN. Kelemahannya terutama pada bagian THEN, yaitu dengan adanya perhitungan matematika sehingga tidak dapat menyediakan kerangka alami untuk representasikan pengetahuan manusia dengan sebenarnya. [7]

Studi pustaka dan literatur diatas, akan dijadikan sebagai landasan untuk melaksanakan penelitian ini, dimana penelitian yang akan di lakukan berfokus pada identifikasi hama tanaman padi melalui penerapan sistem pakar dengan metode fuzzy sugeno dalam upaya pengendalian terhadap gangguan hama. Maka berdasarkan studi pustaka dan literature, maka dapat disimpulkan bahwa masalah hama pada tanaman padi di kabupaten Tegal menyebabkan kegagalan panen karena ketidaktahuannya serta kurangnya pengetahuan para petani dalam mengendalikan hama yang menyerang tanaman padi mereka pada saat masa tanam, namun para petani masih menganggap gejala tersebut sudah biasa hingga petani mulai khawatir saat timbul gejala yang sangat parah dan meluas, dan akhirnya sudah terlambat untuk dikendalikan.

Kabupaten Tegal merupakan salah satu daerah yang memperoleh penghargaan dari Presiden RI atas keberhasilannya dalam meningkatkan produksi padi atau gabah yang mencapai 368.458,57 ton gabah. Komoditas produksi tanaman padi di kabupaten Tegal dari tahun 20102015 mengalami kondisi yang naik turun, dimana pada tahun 2010 produksi padi atau gabah yang mencapai $368.458,57$ ton gabah. Pada tahun 2011 total produksi padi menjadi sebanyak $341.480,33$ ton gabah. Pada tahun 2012 produksi menurun sedikit menjadi 341.006,95 ton gabah, dan sempat turun ditahun 2013 menjadi 211.543,00 ton sebelum naik lagi di tahun 2014 menjadi 317.821,02 ton. Pada tahun 2015 hanya mengalami sedikit kenaikan yaitu 317.821,16 
ton dalam kondisi seperti ini disebabkan oleh beberapa faktor masalah seperti proses perawatan dan cara bertanam yang tidak tepat, menurunnya kualitas hasil padi, kurangnya memperhatikan laju pertumbuhan dan perkembangan tumbuhan padi, ketidaktepatan dalam memilih musim produksi seperti kondisi iklim dan suhu, lingkungan yang cocok, selain itu disebabkan oleh tingginya intensitas serangan hama yang menyerang tanaman padi sehingga menyebabkan petani mengalami gagal panen. Untuk itu diperlukan identifikasi lebih lanjut terhadap hama yang menyerang tanaman padi [2].

Berdasarkan hasil pengumpulan data dari dinas pertanian kabupaten Tegal, pada tabel dan grafik dibawah ini:

Tabel 1.Tingkat Produksi Tanaman Padi Beserta Data Hama di Kabupaten Tegal

\begin{tabular}{|c|c|c|c|c|}
\hline No & Tahun & $\begin{array}{c}\text { Jumlah komoditas produksi } \\
\text { (ton) }\end{array}$ & $\begin{array}{c}\text { Selisih } \\
\text { perbandingan } \\
\text { tahun } \\
\text { sebelumnya(\%) }\end{array}$ & $\begin{array}{c}\text { Luas lahan } \\
\text { yang terserang } \\
\text { Hama (hektar) }\end{array}$ \\
\hline 1 & 2010 & $368.450,57$ & $0 \%$ & 3372 \\
\hline 2 & 2011 & $341.480,33$ & $-7 \%$ & 3193 \\
\hline 3 & 2012 & $341.006,95$ & $0 \%$ & 2177 \\
\hline 4 & 2013 & $211.543,00$ & $-38 \%$ & 1832 \\
\hline 5 & 2014 & $317.821,02$ & $50 \%$ & 1304 \\
\hline 6 & 2015 & $317.821,16$ & $0 \%$ & 1431 \\
\hline
\end{tabular}

Sumber data: Dinas Pertanian Kabupaten Tegal, Tahun 2010-2015

Berdasarkan tabel 1 dapat disimpulkan bahwa komoditas produksi tanaman padi dari tahun 2010-2015 mengalami kondisi yang naik turun, dimana tahun 2010 menghasilkan komoditas padi sebanyak 368.450,57 ton, pada tahun tahun 2011 menghasilkan komoditas padi sebanyak 341.480,33 ton, tahun 2012 menghasilkan komoditas padi sebanyak 341.006,95 ton, tahun 2013 menghasilkan komoditas padi sebanyak 211.543,33 ton, tahun 2014 menghasilkan komoditas padi sebanyak 317.821,02 ton. Dan pada tahun 2015 menghasilkan komoditas padi sebanyak $317.821,16$ ton.

Berdasarkan hasil tersebut dan hasil survey dilapangan menunjukan bahwa, komoditas produksi tanaman padi dari tahun 2010-2015 mengalami kondisi yang naik turun dimana pada tahun 2010 produksi padi yang mencapai $368.450,57$ ton turun drastis di tahun 2013 sebanyak 211.543,33 ton hingga di tahun 2015 hanya mengalami sedikit kenaikan sebanyak 317,821,16 ton. Banyaknya permintaan dan kebutuhan produksi padi yang terus meningkat setiap tahunnya belum dapat diikuti oleh peningkatan produksinya, hal ini dikarenakan hama yang menyerang tanaman padi. Serta kurangnya pengetahuan para petani dalam menangani permasalahan hama yang menyerang tanaman padi, yang mengakibatkan tanaman produksi padi menjadi tidak stabil, hal ini dikarenakan kurangnya pakar dalam mengatasi solusi terbaik dari permasalahan tersebut. Ketidaktepatan dalam memilih musim produksi serta kesalahan dalam memilih obat yang akan digunakan oleh para petani dan komposisi obat yang digunakan untuk menanggulangi hama pada tanaman padi. Untuk itu diperlukan identifikasi lebih lanjut terhadap hama yang menyerang tanaman padi.

Fokus masalah dalam penelitian ini adalah banyaknya hama yang menyerang tanaman padi, hal ini dikarenakan kurangnya pengetahuan para petani dalam menangani permasalahan hama yang menyerang tanaman padi diantaranya serangan hama tikus, serangan hama penggerek batang, serangan hama wereng dan lain sebagainya, serta kurangnya pakar dalam mengatasi solusi terbaik dari permasalahan tersebut. Untuk itu diperlukan identifikasi yang lebih serius dalam menangani hama pada tanaman padi. 


\section{METODE PENELITIAN}

Tahapan - tahapan yang akan dilakukan dalam penelitian ini adalah:

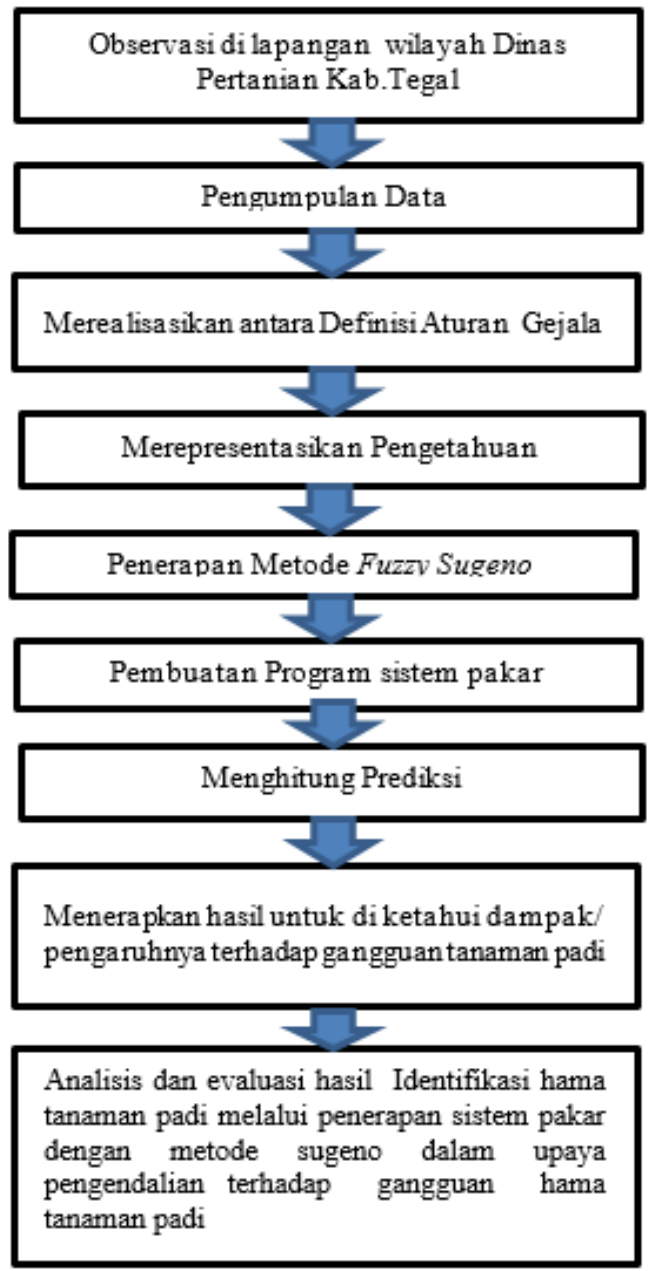

Gambar 1. Tahapan Pelaksanaan Penelitian

Berdasarkan gambar 1 Tahapan pelaksanaan penelitian diatas menjelaskan tahapan demi tahapan penelitian yang akan dilakukan selama melaksanakan penelitian berlangsung, dimana bertujuan untuk dapat menghasilkan penelitian yang ingin dicapai, penjelasan tahapan tahapan tersebut, adalah:

1. Melakukan Observasi di Lapangan wilayah Dinas Pertanian dan Ketahanan Pangan Kab. Tegal

Observasi di lapangan dilakukan dengan terjun ke area sawah wilayah di kabupaten Tegal langsung, dimana peneliti melakukan observasi, wawancara dan studi pustaka untuk mengambil data - data yang mendukung penelitian ini. Dimana data-data yang diperoleh akan dimasukan kedalam laporan penelitian, selama penelitian berlangsung.

2. Pengumpulan data pendukung penelitian

Pengumpulan data pendukung penelitian dilakukan baik mengumpulkan dokumen internal dan eksternal, sebagai dasar dilakukannya penelitian ini, sehingga hasil yang diperoleh dari penelitian ini dapat dimanfaatkan oleh stakeholder khususnya civitas Dinas Pertanian Kabupaten Tegal.

3. Merealisasikan Aturan dan Gejala 
Data yang diperoleh, bersumber dari jurnal, paper, proseding dan buku - buku, dan hasil dari proses wawancara kepada Kabid, Kasi pertanian dan holtikultura, pakar tanaman padi, Ir Mulyono S.ip dari Dinas Pertanian dan Ketahanan Pangan Kabupaten Tegal, setelah memperoleh data - data mengenai jenis hama dan gejala hama pada tanaman padi untuk memudahkan pembacaan data. Maka penulis mengelompokan data tersebut berdasarkan nama hama, gejala hama dan solusi dalam penanganan hama pada tanaman padi, untuk mempermudah pembacaan data maka penulis membuat pengkodean terhadap data nama hama, data gejala hama dan data solusi dalam penanganan hama pada tanaman padi.

4. Merepresentasikan Pengetahuan

Basis pengetahuan yang di gunakan didalam sistem pakar ini terdiri dari gejala-gejala hama pada tanaman padi dan hasil diagnosa yang diberikan oleh pakar.

5. Merancang Database Sistem pakar

Beberapa Tahapan dalam perancangan Database adalah:

a. Pengumpulan data dan analisis

b. Perancangan database secara konseptual

c. Pemilihan sistem manajemen database

d. Perancangan database secara logika

e. Perancangan database secara fisik

f. Implementasi sistem database

6. Menerapkan metode Fuzzy Sugeno

Menerapkan metode fuzzy sugeno yang digunakan sebagai alat menghitung hasil penanganan dari hama tanaman padi

7. Pembuatan Program Sistem Pakar

Merancang program untuk mengidentifikasi hama tanaman padi melalui penerapan sistem pakar dalam upaya pengendalian terhadap serangan hama.

8. Menghitung Prediksi

Dari hasil perhitungan yang dilakukan oleh sistem menggunakan metode fuzzy sugeno maka dilakukan evaluasi, prediksi atau diagnosa apa yang dihasilkan oleh sistem.

9. Menerapkan hasil untuk di ketahui dampak/pengaruhnya terhadap tanaman padi.

Hasil sistem yang sudah terbuat maka di uji cobakan kepada para petani padi yang mengalami kendala pada hama, untuk mendiagnosa hama pada tanaman padi serta menghasilkan cara pencegahan dan cara pengobatannya dan menganalisa seberapa besar pengaruhnya, dan seberapa besar kontribusi dalam menangani hama pada tanaman padi bagi petani padi di kabupaten Tegal.

10.Menganalisis dan mengevaluasi hasil identifikasi hama tanaman padi melalui penerapan sistem pakar dengan metode fuzzy sugeno dalam upaya pengendalian terhadap gangguan hama. Menganalisa hasil dari questioner dan angket untuk di evaluasi untuk diketahui diterima atau tidaknya identifikasi hama tanaman padi melalui penerapan sistem pakar dengan metode fuzzy sugeno dalam upaya pengendalian terhadap gangguan hama.

\section{HASIL DAN PEMBAHASAN}

\section{Kaidah Produksi}

Representasi kaidah produksi adalah menghadirkan pengetahuan yang ada sebagai kaidah produksi dalam bentuk aksi yaitu pasangan IF kondisi (premis) terjadi THEN aksi (konklusi atau kesimpulan). Berikut adalah tabel aturan kaidah produksi untuk identikasi hama tanaman padi. 
Tabel 2. Kaidah Produksi

\begin{tabular}{|c|c|c|}
\hline $\begin{array}{l}\text { ATURAN } \\
\text { KE- }\end{array}$ & GEJALA (IF) & HAMA (THEN) \\
\hline 1 & $\begin{array}{l}\text { G001 AND G003 AND G004 AND G005 AND G006 } \\
\text { AND G012 AND G013 }\end{array}$ & H001 \\
\hline 2 & G007 AND G008 AND G009 AND G010 AND G011 & $\mathrm{H} 002$ \\
\hline 3 & G014 AND G015 AND G016 AND G017 AND G018 & $\mathrm{H} 003$ \\
\hline 4 & $\begin{array}{l}\text { G019 AND G020 AND G021 AND G022 AND G023 } \\
\text { AND G024 AND G025 AND G026 }\end{array}$ & H004 \\
\hline 5 & G014 AND G015 AND G016 AND G017 & $\mathrm{H} 005$ \\
\hline 6 & $\begin{array}{l}\text { G002 AND G027 AND G028 AND G029 AND G030 } \\
\text { AND G031 AND G032 AND G033 }\end{array}$ & H006 \\
\hline 7 & G034 AND G035 AND G036 & $\mathrm{H} 007$ \\
\hline 8 & $\begin{array}{l}\text { G037 AND G038 AND G039 AND G040 AND G041 } \\
\text { AND G042 }\end{array}$ & H008 \\
\hline 9 & G043 AND G045 AND G046 & H009 \\
\hline 10 & G047 AND G048 AND G049 & $\mathrm{H} 010$ \\
\hline 11 & $\begin{array}{l}\text { G022 AND G050 AND G051 AND G052 AND G053 } \\
\text { AND G053 }\end{array}$ & H011 \\
\hline 12 & G055 AND G056 AND G057 AND G058 AND G059 & H012 \\
\hline 13 & G060 AND G014 AND G024 & H013 \\
\hline 14 & G060 AND G061 & H014 \\
\hline 15 & G062 AND G063 & H015 \\
\hline 16 & G064 AND G065 AND G066 AND G067 AND G068 & $\mathrm{H} 016$ \\
\hline 17 & G021 AND G069 AND G070 AND G071 AND G072 & H017 \\
\hline 18 & G073 AND G074 AND G075 AND G076 & H018 \\
\hline 19 & G054 AND G044 AND G077 AND G078 & H019 \\
\hline
\end{tabular}

2. Pembentukan Aturan (Rule)

Pembentukan aturan ini digunakan untuk menentukan proses pencarian atau menentukan kesimpulan dari identifikasi. Berikut tabel hama tanaman padi:

Tabel 3. Hama Tanaman Padi

\begin{tabular}{|c|l|}
\hline Kode Hama & \multicolumn{1}{|c|}{ Nama Hama } \\
\hline H001 & $\begin{array}{l}\text { Hama Penggerek Batang Padi } \\
\text { Kuning (Scirpophaga } \\
\text { incertulas Walkers) }\end{array}$ \\
\hline H002 & $\begin{array}{l}\text { Hama Putih Palsu / Pelipat } \\
\text { Daun (Cnaphalocrosos } \\
\text { medinalis Guenee) }\end{array}$ \\
\hline H006 & $\begin{array}{l}\text { Hama Wereng Batang Coklat ( } \\
\text { Nilaparvata lugrns Stal) }\end{array}$ \\
\hline H007 & $\begin{array}{l}\text { Hama Wereng Hijau.( } \\
\text { Nephotettix Virescens Distant) }\end{array}$ \\
\hline H008 & $\begin{array}{l}\text { Hama Wereng Punggung } \\
\text { Putih. (Sogatella Furcifera } \\
\text { Horvarth) }\end{array}$ \\
\hline H009 & $\begin{array}{l}\text { Hama Putih / Penggulung } \\
\text { Daun (Nymphula depunctalis } \\
\text { Guenee) }\end{array}$ \\
\hline
\end{tabular}


Vol. 5, No. 1, September 2018, Hal. 45-59

\begin{tabular}{|c|c|}
\hline Kode Hama & Nama Hama \\
\hline H011 & $\begin{array}{l}\text { Hama Ulat Grayak ( } \\
\text { Spodoptera mauritia Boisd, } \\
\text { Mymthimna separate Walker) }\end{array}$ \\
\hline H012 & $\begin{array}{l}\text { Hama Walang Sangit ( } \\
\text { Leptocorisa oratorius) }\end{array}$ \\
\hline H013 & $\begin{array}{l}\text { Hama Ganjur ( Orselia Oryzae } \\
\text { Wood-Mason) }\end{array}$ \\
\hline H014 & $\begin{array}{l}\text { Hama Belalang Kembara ( } \\
\text { Locusta migratoria) }\end{array}$ \\
\hline H015 & $\begin{array}{l}\text { Hama Kepinding Tanah ( } \\
\text { Scotinopthora coarctata } \\
\text { Fabricus) }\end{array}$ \\
\hline H016 & $\begin{array}{l}\text { Hama Lalat Bibit ( Atherigona } \\
\text { exigua Stein) }\end{array}$ \\
\hline H017 & $\begin{array}{l}\text { Hama Uret / Lundi ( } \\
\text { Phyllophaga Holotrichia } \\
\text { helera Brsk, Leucophalis sp, } \\
\text { Heteronychus sp) }\end{array}$ \\
\hline H018 & $\begin{array}{l}\text { Hama Anjing Tanah / orong- } \\
\text { orong ( Gryllotalpa hirsute } \\
\text { Burm) }\end{array}$ \\
\hline H019 & $\begin{array}{l}\text { Hama Kepik Biji / hitam ( } \\
\text { Paraeucametus Pallicornis) }\end{array}$ \\
\hline H020 & $\begin{array}{l}\text { Hama Tikus ( Rattus } \\
\text { argentiver, Muridae) }\end{array}$ \\
\hline H021 & $\begin{array}{l}\text { Hama Siput murbei / keong } \\
\text { mas ( pomacea caniculata } \\
\text { Lamarck) }\end{array}$ \\
\hline $\mathrm{H} 022$ & $\begin{array}{l}\text { Hama Babi hutan / Celeng ( } \\
\text { Sus scrofa vittatus) }\end{array}$ \\
\hline H023 & $\begin{array}{l}\text { Hama Burung ( Lachura spp. } \\
\text { Ploceus sp) }\end{array}$ \\
\hline
\end{tabular}

\section{Proses Analisis Metode Fuzzy Sugeno}

Untuk menerapkan metode Fuzzy Inference System Takagi-Sugeno-Kang pada sistem, ada beberapa variabel yang diperlukan, yaitu bobot nilai dari setiap gejala, batas nilai, minimum setiap gejala, batas nilai maksimum setiap gejala, dan aturan yang menunjukkan gejalagejala yang dimiliki oleh setiap hama. Berikut Akuisisi Pengetahuan berdasarkan asumsi dari pakar dan penerapan dari logika fuzzy (logika kekaburan) maka range interval dibagi menjadi 3 kategori, yaitu ringan dengan kisaran $(0,0 \leq \mathrm{a} \leq 0,4)$, sedang dengan kisaran $(0,3 \leq$ $\mathrm{a} \leq 0,7)$, dan parah dengan kisaran $(0,6 \leq \mathrm{a} \leq 1)$.

Berikut range interval dari setiap gejala: 


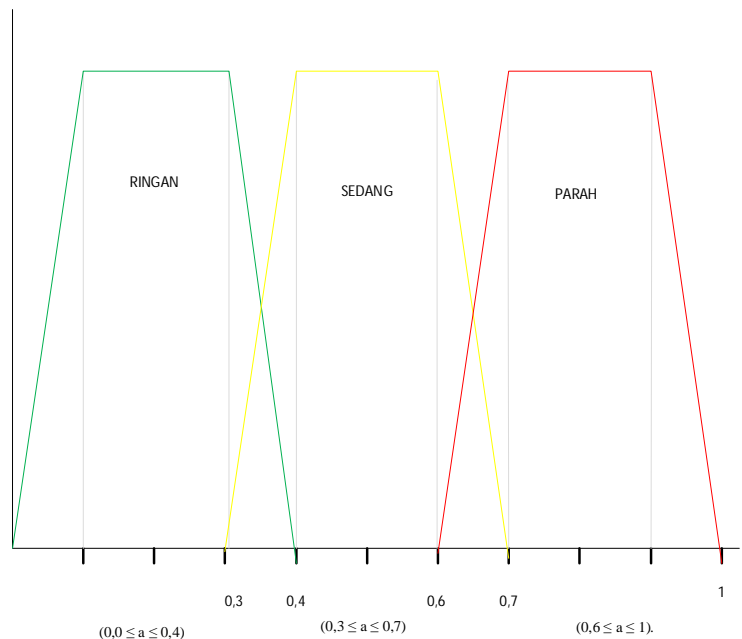

Gambar 2. Range Interval pada Tiap Gejala

Berikut adalah kategori gejala beserta bobot nilai interval setiap gejala. Bobot nilai interval didapatkan dari pengalaman pakar.

Tabel 4. Kategori dan Nilai Interval

\begin{tabular}{|c|l|c|c|l|}
\hline $\begin{array}{c}\text { Kode } \\
\text { Gejala }\end{array}$ & \multicolumn{1}{|c|}{ Nama Gejala } & Kategori & Nilai Bobot & \multicolumn{1}{|c|}{$\begin{array}{c}\text { Range } \\
\text { Interval }\end{array}$} \\
\hline G001 & Daun pucuk tanaman layu & ringan & 0,15 & $(0,0 \leq \mathrm{a} \leq 0,4)$ \\
\hline G002 & $\begin{array}{l}\text { Daun berwarna putih tinggal lapisan } \\
\text { epidermis nya. }\end{array}$ & ringan & 0,15 & $(0,0 \leq \mathrm{a} \leq 0,4)$ \\
\hline G003 & Batang mudah dicabut & parah & 0,8 & $(0,6 \leq \mathrm{a} \leq 1)$ \\
\hline G004 & Daun mengering & sedang & 0,5 & $(0,3 \leq \mathrm{a} \leq 0,7)$ \\
\hline G005 & Seluruh batang kering & parah & 0,8 & $(0,6 \leq \mathrm{a} \leq 1)$ \\
\hline G006 & $\begin{array}{l}\text { Pucuk daun berwarna coklat dan } \\
\text { mudah dicabut (sundep) }\end{array}$ & sedang & 0,5 & $(0,3 \leq \mathrm{a} \leq 0,7)$ \\
\hline G007 & $\begin{array}{l}\text { Adanya warna putih pada daun di } \\
\text { pertanaman }\end{array}$ & ringan & 0,15 & $(0,0 \leq \mathrm{a} \leq 0,4)$ \\
\hline G008 & Daun terlipat tubular & ringan & 0,15 & $(0,0 \leq \mathrm{a} \leq 0,4)$ \\
\hline G009 & $\begin{array}{l}\text { Ujung daun adakalanya diikat ke } \\
\text { bagian basal daun }\end{array}$ & ringan & 0,15 & $(0,0 \leq \mathrm{a} \leq 0,4)$ \\
\hline G010 & $\begin{array}{l}\text { Larva memakan jaringan hijau daun } \\
\text { dari dalam lipatan daun }\end{array}$ & parah & 0,8 & $(0,6 \leq \mathrm{a} \leq 1)$ \\
\hline G011 & Bagian bawah daun berwarna putih & ringan & 0,15 & $(0,0 \leq \mathrm{a} \leq 0,4)$ \\
\hline G012 & Malai mudah dicabut & sedang & 0,5 & $(0,3 \leq \mathrm{a} \leq 0,7)$ \\
\hline G013 & $\begin{array}{l}\text { Pada pangkal batang terdapat bekas } \\
\text { gerekan larva(ulat) penggerek batang }\end{array}$ & parah & 0,8 & $(0,6 \leq \mathrm{a} \leq 1)$ \\
\hline G014 & Daun berwarna kekuningan & sedang & 0,5 & $(0,3 \leq \mathrm{a} \leq 0,7)$ \\
\hline G015 & Batang tanaman berwarna kuning & sedang & 0,5 & $(0,3 \leq \mathrm{a} \leq 0,7)$ \\
\hline G016 & $\begin{array}{l}\text { Seluruh tanaman mengering bagaikan } \\
\text { terbakar. }\end{array}$ & parah & 0,8 & $(0,6 \leq \mathrm{a} \leq 1)$ \\
\hline G017 & $\begin{array}{l}\text { Tanaman mengalami kerdil rumput } \\
\text { atau hampa }\end{array}$ & parah & 0,8 & $(0,6 \leq \mathrm{a} \leq 1)$ \\
\hline G018 & $\begin{array}{l}\text { Tanaman menguning dan cepat sekali } \\
\text { mengering }\end{array}$ & parah & 0,8 & $(0,6 \leq \mathrm{a} \leq 1)$ \\
\hline G019 & Terdapat nimfa muda yang berwarna & ringan & 0,15 & $(0,0 \leq \mathrm{a} \leq 0,4)$ \\
\hline
\end{tabular}

Nurdiawan et.al (Perancangan Pengukur Kekuatan Motor Brushless Berbasis ESP8266) 
Vol. 5, No. 1, September 2018, Hal. 45-59

\begin{tabular}{|c|c|c|c|c|}
\hline $\begin{array}{l}\text { Kode } \\
\text { Gejala }\end{array}$ & Nama Gejala & Kategori & Nilai Bobot & $\begin{array}{l}\text { Range } \\
\text { Interval }\end{array}$ \\
\hline & $\begin{array}{l}\text { putih yang lama kelamaan menjadi } \\
\text { hijau }\end{array}$ & & & \\
\hline G020 & $\begin{array}{l}\text { Daun padi berwarna kuning sampai } \\
\text { kuning oranye }\end{array}$ & ringan & 0,15 & $(0,0 \leq \mathrm{a} \leq 0,4)$ \\
\hline G021 & Penurunan jumlah anakan & ringan & 0,15 & $(0,0 \leq \mathrm{a} \leq 0,4)$ \\
\hline G022 & $\begin{array}{l}\text { Pertumbuhan tanaman terhambat dan } \\
\text { memendek }\end{array}$ & sedang & 0,5 & $(0,3 \leq \mathrm{a} \leq 0,7)$ \\
\hline G023 & $\begin{array}{l}\text { Terdapat tempat bekas hisapan akan } \\
\text { tumbuh cendawan jelaga }\end{array}$ & ringan & 0,15 & $(0,0 \leq \mathrm{a} \leq 0,4)$ \\
\hline G024 & Daun tanaman kering dan mati & sedang & 0,5 & $(0,3 \leq \mathrm{a} \leq 0,7)$ \\
\hline G025 & $\begin{array}{l}\text { Pucuk daun berwarna kuning hingga } \\
\text { kuning kecoklatan }\end{array}$ & ringan & 0,15 & $(0,0 \leq \mathrm{a} \leq 0,4)$ \\
\hline G026 & Malai yang dihasilkan sedikit & ringan & 0,15 & $(0,0 \leq \mathrm{a} \leq 0,4)$ \\
\hline G027 & Daun terpotong seperti digunting & sedang & 0,5 & $(0,3 \leq \mathrm{a} \leq 0,7)$ \\
\hline G028 & $\begin{array}{l}\text { Daun berwarna putih kering dan pucuk } \\
\text { daun terlihat bekas potongan }\end{array}$ & ringan & 0,15 & $(0,0 \leq \mathrm{a} \leq 0,4)$ \\
\hline G029 & $\begin{array}{l}\text { Daun terpotong dilipat menyerupai } \\
\text { tabung }\end{array}$ & ringan & 0,15 & $(0,0 \leq \mathrm{a} \leq 0,4)$ \\
\hline G030 & $\begin{array}{l}\text { Gulungan daun yang berisi larva akan } \\
\text { mengapung di atas permukaan air pada } \\
\text { siang hari dan makan pada malam hari. }\end{array}$ & sedang & 0,5 & $(0,3 \leq \mathrm{a} \leq 0,7)$ \\
\hline G031 & $\begin{array}{l}\text { Daun bergulung diisi air untuk } \\
\text { bernafas }\end{array}$ & ringan & 0,15 & $(0,0 \leq \mathrm{a} \leq 0,4)$ \\
\hline G032 & $\begin{array}{l}\text { terdapat garis-garis putih transparan } \\
\text { sepanjang } 15-20 \mathrm{~cm}\end{array}$ & ringan & 0,15 & $(0,0 \leq a \leq 0,4)$ \\
\hline G033 & $\begin{array}{l}\text { Daun bendera (daun yang tegak lurus } \\
\text { ke atas) ikut rusak. }\end{array}$ & sedang & 0,5 & $(0,3 \leq \mathrm{a} \leq 0,7)$ \\
\hline G034 & Daun tanaman rusak & parah & 0,8 & \\
\hline G035 & $\begin{array}{l}\text { Terdapat telur-telur ulat grayak/ulat } \\
\text { tentara pada tanaman }\end{array}$ & sedang & 0,5 & $(0,3 \leq \mathrm{a} \leq 0,7)$ \\
\hline G036 & $\begin{array}{l}\text { Daun berlubang dimakan ulat mulai } \\
\text { dari tepi daun sampai hanya } \\
\text { meninggalkan tulang daun dan batang }\end{array}$ & parah & 0,8 & $(0,6 \leq \mathrm{a} \leq 1)$ \\
\hline G037 & Bulir padi rusak & parah & 0,8 & $(0,6 \leq a \leq 1)$ \\
\hline G038 & Gabah kecil dan menciut & parah & 0,8 & $(0,6 \leq a \leq 1)$ \\
\hline G039 & Malai tegak & parah & 0,8 & $(0,6 \leq a \leq 1)$ \\
\hline G040 & Gabah cacat atau spotty grains & parah & 0,8 & $(0,6 \leq a \leq 1)$ \\
\hline G041 & Bulir padi hampa dan berwarna hitam & parah & 0,8 & $(0,6 \leq \mathrm{a} \leq 1)$ \\
\hline G042 & $\begin{array}{l}\text { Buah padi berbintik-bintik } \\
\text { hitam(bercak coklat) }\end{array}$ & parah & 0,8 & $(0,6 \leq a \leq 1)$ \\
\hline G043 & $\begin{array}{l}\text { Daun menggulung seperti daun } \\
\text { bawang }\end{array}$ & ringan & 0,15 & $(0,0 \leq \mathrm{a} \leq 0,4)$ \\
\hline G044 & Gabah berserakan & parah & 0,8 & $(0,6 \leq a \leq 1)$ \\
\hline G045 & $\begin{array}{l}\text { Pertumbuhan padi menjadi tidak } \\
\text { normal }\end{array}$ & ringan & 0,15 & $(0,0 \leq \mathrm{a} \leq 0,4)$ \\
\hline G046 & Anakan tidak menghasilkan malai & parah & 0,8 & $(0,6 \leq \mathrm{a} \leq 1)$ \\
\hline G047 & Daun berbentuk tidak beraturan & ringan & 0,15 & $(0,0 \leq \mathrm{a} \leq 0,4)$ \\
\hline G048 & Tanaman hanya tinggal tulang-tulang & sedang & 0,5 & $(0,3 \leq \mathrm{a} \leq 0,7)$ \\
\hline
\end{tabular}




\begin{tabular}{|c|c|c|c|c|}
\hline $\begin{array}{l}\text { Kode } \\
\text { Gejala }\end{array}$ & Nama Gejala & Kategori & Nilai Bobot & $\begin{array}{c}\text { Range } \\
\text { Interval }\end{array}$ \\
\hline & daun & & & \\
\hline G049 & $\begin{array}{l}\text { Adanya lubang - lubang pada daun } \\
\text { sampai habis tidak tersisa }\end{array}$ & sedang & 0,5 & $(0,3 \leq \mathrm{a} \leq 0,7)$ \\
\hline G050 & $\begin{array}{l}\text { Warna cokelat disekitar bagian } \\
\text { pelepah dan batang }\end{array}$ & ringan & 0,15 & $(0,0 \leq \mathrm{a} \leq 0,4)$ \\
\hline G051 & $\begin{array}{l}\text { Tanaman berwarna kuning, kering dan } \\
\text { membusuk }\end{array}$ & parah & 0,8 & \\
\hline G052 & $\begin{array}{l}\text { Daun menjadi kering dan menggulung } \\
\text { secara membujur }\end{array}$ & ringan & 0,15 & $(0,0 \leq \mathrm{a} \leq 0,4)$ \\
\hline G053 & Malai pendek & ringan & 0,15 & $(0,0 \leq \mathrm{a} \leq 0,4)$ \\
\hline G054 & Gabah hampa & parah & 0,8 & $(0,6 \leq \mathrm{a} \leq 1)$ \\
\hline G055 & $\begin{array}{l}\text { Bercak - bercak kuning yang dapat } \\
\text { dilihat disepanjang tepi daun yang baru } \\
\text { muncul }\end{array}$ & ringan & 0,15 & $(0,0 \leq \mathrm{a} \leq 0,4)$ \\
\hline G056 & Terdapat larva lalat pada tanaman & sedang & 0,5 & $(0,3 \leq \mathrm{a} \leq 0,7)$ \\
\hline G057 & Daun mengalami perubahan bentuk & ringan & 0,15 & $(0,0 \leq \mathrm{a} \leq 0,4)$ \\
\hline G058 & Anakan menjadi berkurang & sedang & 0,5 & $(0,3 \leq \mathrm{a} \leq 0,7)$ \\
\hline G059 & Terdapat larva lalat pada tanaman & parah & 0,8 & $(0,6 \leq a \leq 1)$ \\
\hline G060 & Tanaman layu seperti kekurangan air & ringan & 0,15 & $(0,0 \leq \mathrm{a} \leq 0,4)$ \\
\hline G061 & $\begin{array}{l}\text { Akar rusak dan bagian pangkal } \\
\text { tanaman yang berada di bawah tanah }\end{array}$ & parah & 0,8 & $(0,6 \leq \mathrm{a} \leq 1)$ \\
\hline G062 & $\begin{array}{l}\text { Bulir padi berwarrna cokelat } \\
\text { kehitaman }\end{array}$ & sedang & 0,5 & $(0,3 \leq \mathrm{a} \leq 0,7)$ \\
\hline G063 & $\begin{array}{l}\text { Bulir padi mudah hancur dan apabila } \\
\text { dimasak terasa pahit }\end{array}$ & parah & 0,8 & $(0,6 \leq \mathrm{a} \leq 1)$ \\
\hline G064 & $\begin{array}{l}\text { Terdapat potongan batang membentuk } \\
\text { serong }\end{array}$ & parah & 0,8 & $(0,6 \leq a \leq 1)$ \\
\hline G065 & Tanaman roboh atau rebah & parah & 0,8 & $(0,6 \leq a \leq 1)$ \\
\hline G066 & $\begin{array}{l}\text { Dipinggir petakan hanya tersisa } 1-2 \\
\text { baris tanaman }\end{array}$ & parah & 0,8 & $(0,6 \leq \mathrm{a} \leq 1)$ \\
\hline G067 & $\begin{array}{l}\text { Terdapat tikus, liang tikus, kotoran } \\
\text { tikus dan jejak tikus }\end{array}$ & parah & 0,8 & $(0,6 \leq \mathrm{a} \leq 1)$ \\
\hline G068 & $\begin{array}{l}\text { Ada potongan-potongan padi bekas } \\
\text { dirusak tikus }\end{array}$ & parah & 0,8 & $(0,6 \leq \mathrm{a} \leq 1)$ \\
\hline G069 & Akar tanaman rusak & parah & 0,8 & $(0,6 \leq a \leq 1)$ \\
\hline G070 & Bibit yang hilang di pertanaman & parah & 0,8 & $(0,6 \leq a \leq 1)$ \\
\hline G071 & $\begin{array}{l}\text { Terdapat Bekas potongan daun dan } \\
\text { batang yang terlihat mengambang }\end{array}$ & sedang & 0,5 & $(0,3 \leq \mathrm{a} \leq 0,7)$ \\
\hline G072 & $\begin{array}{l}\text { Terdapat telur keong berwarna merah } \\
\text { pada batang }\end{array}$ & sedang & 0,5 & $(0,3 \leq \mathrm{a} \leq 0,7)$ \\
\hline G073 & $\begin{array}{l}\text { Adanya bekas kubangan dalam lumpur } \\
\text { pada area tanaman padi }\end{array}$ & sedang & 0,5 & $(0,3 \leq \mathrm{a} \leq 0,7)$ \\
\hline G074 & Rusaknya tanaman padi & parah & 0,8 & $(0,6 \leq a \leq 1)$ \\
\hline G075 & Adanya bekas jejak kaki babi hutan & parah & 0,8 & $(0,6 \leq a \leq 1)$ \\
\hline G076 & $\begin{array}{l}\text { Adanya sarang yang terbuat dari } \\
\text { rumput - rumputan, alang- alang, } \\
\text { kayu- kayu tanaman kecil atau rotan di } \\
\text { area sekitar penanaman tanaman padi }\end{array}$ & sedang & 0,5 & $(0,3 \leq \mathrm{a} \leq 0,7)$ \\
\hline
\end{tabular}


Vol. 5, No. 1, September 2018, Hal. 45-59

\begin{tabular}{|c|l|c|c|c|}
\hline $\begin{array}{c}\text { Kode } \\
\text { Gejala }\end{array}$ & \multicolumn{1}{|c|}{ Nama Gejala } & Kategori & Nilai Bobot & $\begin{array}{c}\text { Range } \\
\text { Interval }\end{array}$ \\
\hline G077 & Terdapat burung di area tanaman & sedang & 0,5 & $(0,3 \leq \mathrm{a} \leq 0,7)$ \\
\hline G078 & Tangkai malai patah & parah & 0,8 & $(0,6 \leq \mathrm{a} \leq 1)$ \\
\hline
\end{tabular}

Berikut ini tahapan-tahapan yang digunakan dalam metode Fuzzy Inference System TakagiSugeno-Kang, yaitu:

1. Pembentukan himpunan Fuzzy/Fuzzyfikasi

Tahapan ini merupakan tahapan untuk mengubah variabel numerik (variabel non fuzzy) berupa bobot nilai, batas interval minimum dan maksimum dari gejala yang dipilih menjadi variabel linguistik (variabel fuzzy) dengan rumus fuzzyfikasi sehingga didapatkan nilai fuzzy.

2. Aplikasi fungsi implikasi

Contoh pembentukan aturan premis pada sistem pakar ini yaitu IF gejala $=$ G001 AND G003 AND G004 AND G005 AND G006 AND G012 AND G013 then hama = H001. Berdasarkan aturan yang telah dibentuk pada tahap akuisisi pengetahuan, didapatkan sebanyak 19 aturan.

3. Defuzzifikasi

Tahapan ini merupakan tahapan akhir dari logika fuzzy dimana setelah dilakukan fuzzyfikasi pada tiap gejala yang dipilih, kemudian dari gejala-gejala tersebut diproses berdasarkan aturan dari fungsi implikasi yang telah dibuat sehingga didapatkan hasil hama.

Berikut contoh penyelesaian identifikasi hama menggunakan metode fuzzy sugeno. Untuk memproses H001 (Hama Penggerek Batang), dengan gejala - gejala sebagai berikut:

Tabel 5. Keputusan Hama Penggerek Batang

\begin{tabular}{|c|l|l|c|}
\hline Kode Hama & \multicolumn{1}{|c|}{ Nama Hama } & Kategori & Nilai Bobot \\
\hline G001 & Daun pucuk tanaman layu & ringan & 0,15 \\
\hline G003 & Batang mudah dicabut & parah & 0,8 \\
\hline G004 & Daun mengering & sedang & 0,5 \\
\hline G005 & Seluruh batang kering & parah & 0,8 \\
\hline G006 & $\begin{array}{l}\text { Pucuk daun berwarna coklat } \\
\text { dan mudah dicabut (sundep) }\end{array}$ & sedang & 0,5 \\
\hline G012 & Malai mudah dicabut & sedang & 0,5 \\
\hline
\end{tabular}

1. Menghitung proses fuzzifikasi dengan rumus sebagai berikut:

Rumus umum untuk fuzzifikasi metode Fuzzy Inference SystemTakagi Sugeno-Kang yaitu sebagai berikut:

$$
\begin{aligned}
& \mu[x, a, b, c]=\left\{\begin{array}{ll}
0 \quad & x \leq a \text { atau } x \geq c \\
\frac{(x-a)}{(b-a)} ; & a \leq x \leq b \\
\frac{(c-x)}{(c-b)} ; & b \leq x \leq c
\end{array} .\right. \\
& b=\frac{\sum a \text { sampai } b}{n}
\end{aligned}
$$

Keterangan:

$\mathrm{x}=$ Bobot nilai yang sudah ditentukan pada setiap gejala yang dipilih

$\mathrm{a}=$ Batas nilai minimum pada setiap gejala

$\mathrm{b}=$ Nilai tengah dari batas minimum dan maksimum

$\mathrm{c}=$ Batas nilai maksimum pada setiap gejala 
Selanjutnya, menghitung nilai $\mathrm{b}$ (nilai tengah dari batas minimum dan maksimum) dari setiap kategori tingkat keparahan ringan, sedang, parah. Dengan rumus sebagai berikut:

$$
b=\frac{\sum a \text { sampai } b}{n}
$$

a) Ringan dengan range interval $(0,0 \leq \mathrm{a} \leq 0,4)$

$$
b=\frac{0,0+0,1+0,2+0,3+0,4}{5}=\frac{1}{5}=0,2
$$

Jadi nilai tengah dari batas minimum dan maksimum pada kategori ringan adalah 0,2

b) Sedang dengan range interval $(0,3 \leq \mathrm{a} \leq 0,7)$

$$
b=\frac{0,3+0,4+0,5+0,6+0,7}{5}=\frac{2,5}{5}=0,5
$$

Jadi nilai tengah dari batas minimum dan maksimum pada kategori sedang adalah 0,5

c) Parah dengan range interval $(0,6 \leq \mathrm{a} \leq 1)$

$$
b=\frac{0,6+0,7+0,8+0,9+1}{5}=\frac{4}{5}=0,8
$$

Jadi nilai tengah dari batas minimum dan maksimum pada kategori sedang adalah 0,5

2. Menghitung nilai fuzzifikasi dari G001, G003, G004, G005, G006, G012, G013.

Sistem menampilkan pilihan "G1" dan "G3". Kemudian user memilih "G1" dimana gejala ini memiliki bobot nilai 0,15 dengan batas $0 \leq \mathrm{a} \leq 0,4$. Masuk dalam kategori ringan. Selanjutnya dilakukan proses fuzzyfikasi dengan rumus sebagai berikut:

a) Menghitung F (G001)

$$
F=\frac{(x-a)}{(b-a)}
$$

$$
F=\frac{(0,15-0,0)}{(0,2-0,0)}=0,75
$$

Jadi hasil proses fuzzyfikasi G001 adalah 0,75

b) Menghitung F (G004,G005,G013), gejala ini memiliki bobot nilai 0,8 dengan batas $0,6 \leq \mathrm{a}$ $\leq 1$, masuk dalam kategori parah

$$
F=\frac{(0,8-0,6)}{(0,8-0,6)}=1
$$

Jadi hasil proses fuzzyfikasi G003 adalah 1

c) Menghitung F (G004, G006, G012), gejala ini memiliki bobot nilai 0,5 dengan batas $0,3 \leq \mathrm{a}$ $\leq 0,7$, masuk dalam kategori sedang 


$$
F=\frac{(0,5-0,3)}{(0,5-0,3)}=1
$$

Jadi hasil proses fuzzyfikasi G004, G005, G006, G012 adalah 1

3. Menghitung Proses Defuzzifikasi

Rumus umum untuk defuzzifikasi metode Fuzzy Inference System Takagi Sugeno-Kang yaitu sebagai berikut:

Keterangan:

$\mathrm{WA}=($ Weighted Average $)$ Nilai rata-rata

$\mathrm{a}_{\mathrm{n}}=$ Nilai predikat aturan ke-n

$\mathrm{z}_{\mathrm{n}}=$ Indeks nilai input(konstanta) ke-n

$$
\mathrm{WA}=\frac{\alpha 1 \mathrm{z} 1+\alpha 2 \mathrm{z} 2+\alpha 3 \mathrm{z} 3+\ldots+\alpha \mathrm{nzn}}{\alpha 1+\alpha 2+\alpha 3+\ldots+\alpha \mathrm{n}}
$$

$\mathbf{W A}=($ F.G001 x BN.G001) $+($ F.G003 x BN.G001) $+($ F.G004 BN.G001) $+($ F.G005 x BN.G001) + (F.G006 x BN.G001) + (F.G012 x BN.G001) + (F.G013 x BN.G001) / F.G001+ F.G003 + F.G004 + F.G005 + F.G006 + F.G012 + F.G013

$=((0,75 \times 0,15)+(1 \times 0,8)+(1 \times 0,5)+(1 \times 0,8)+(1 \times 0,5)+(1 \times 0,5)+(1 \times 0,8)) /$ $0,75+1+1+1+1+1+1$

$=(0,1125+0,8+0,5+0,8+0,5+0,5+0,8) /(6,75)$

$=4,0125 / 6,75$

$=0,5944$

Maka, nilai defuzzifikasi (Tingkat keparahan hama) adalah 0,5944 x 100\% $=\mathbf{5 9 , 4 4} \%$

Maka dapat disimpulkan bahwa hasil defuzzifikasi (Tingkat keparahan hama) pada H001 (Hama Penggerek Batang) adalah 59,44\%. Maka masuk dalam kategori serangan

Berat. Berdasarkan data berat serangan hama yang dibagi menjadi 4 kategori yaitu:

Ringan : Bila tingkat serangan > ambang pengendalian $-\leq 25 \%$

Sedang : $\geq 25 \%-\leq 50 \%$

Berat $\quad: \geq 50 \%-\leq 75 \%$

Puso $\quad: \geq 75 \%$

4. Implementasi hasil

a) Halaman Utama

Halaman ini merupakan tampilan awal dari sistem pakar identifikasi hama pada tanaman padi saat program dijalankan. Halaman ini memuat, petunjuk menggunakan sistem, serta penjelasan mengenai sistem pakar identifikasi hama pada tanaman padi. Adapun implementasi halaman utama dapat dilihat pada gambar 3:

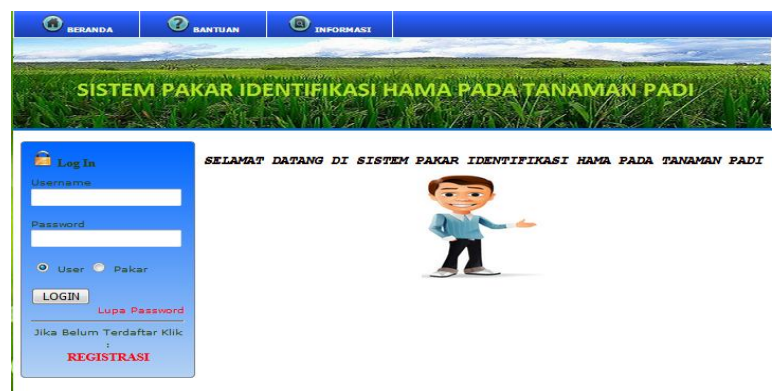

Gambar 3. Sistem pakar 
b) Halaman Konsultasi Hama

Halaman Konsultasi Hama digunakan untuk user yang akan melakukan diagnosa hama pada tanaman padi. Pada halaman konsultasi hama, akan ditampilkan gejala - gejala dalam bentuk pertanyaan yang akan dipilih oleh user. Adapun implementasi Halaman Konsultasi hama dapat dilihat pada gambar berikut:

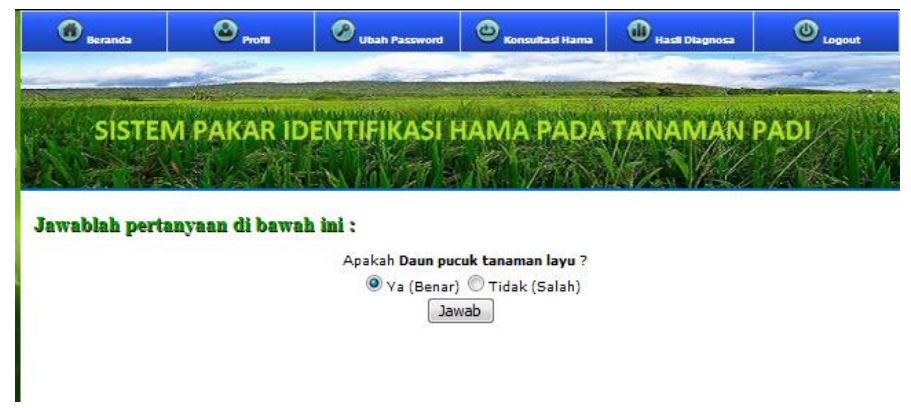

Gambar 4. Sistem Pakar

\section{KESIMPULAN}

Beberapa kesimpulan yang dapat diambil dari Penerapan Sistem Pakar Menggunakan Metode Fuzzy Sugeno Identifikasi Hama Tanaman Padi dalam upaya pengendalian terhadap gangguan hama adalah sebagai berikut:

1. Sistem pakar identifikasi hama tanaman padi dapat mengidentifikasi hama pada tanaman padi dan dapat mengendalian gangguan hama tanaman padi.

2. Penanganan identifikasi hama tanaman padi menjadi lebih cepat dengan adanya sistem pakar identifikasi hama tanaman padi.

\section{DAFTAR PUSTAKA}

[1] Chandra Irsan, dkk. 2014, Pengendalian Tikus dan Walang Sangit di Padi Organik Sawah Lebak Control of Rats and Bugs at Paddy Organic on Swamp Land, Prosiding Seminar Nasional Lahan Suboptimal 2014, 797-805.

[2] Dinas Pertanian Kab Tegal. 2015, Komoditas Produksi Padi tahun 2015, Tegal: Dinas Kab Tegal.

[3] Erwan Eko Prasetiyo. 2016, Perbandingan Kinerja Pengendali Lampu Lalu Lintas Metode Fuzzy Tipe Sugeno Dengan Metode Waktu Tetap, Seminar Nasional Teknologi Informasi dan Multimedia 2016, 6-7.

[4] Kurniawan. 2012, Analisis Sistem dan Sumber Daya Informasi, Ekonomi, 6, 1-23.

[5] Kusrini. 2008, Aplikasi Sistem Pakar Menentukan Faktor Kepastian Dengan metode Kuantifikasi Pertanyaan, (Dwi Prabantini, Ed.), ANDI, Yogyakarta.

[6] Muhammad Arsyad. 2014, Implementasi Metode Sugeno Pada Sistem Pakar Penentuan Stadium Pada Penyakit Tuberculosis (TBC), Pelita Informatika Budi Darma, 11(3), 2227. 
[7] Yulianto, dkk. 2015, Model Sistem Pakar Diagnosa Hama Tanaman Padi untuk Memberikan Solusi Penanggulangan, Seminar Nasional Teknologi Informasi dan Multimedia 2015, 6-8. 